\title{
Graves Hastalığının Remisyon Döneminde Sessiz Tiroidit
}

\section{A Silent Thyroiditis in the Remission Period of Graves' Disease}

Cem Onur Kıraç ${ }^{1}$,

Süleyman Hilmi İpekçi ${ }^{1}$,

Gonca Kara Gedik²,

Levent Kebapcılar ${ }^{1}$,

${ }^{1}$ Selçuk Üniversitesi, Tıp Fakültesi,

Endokrinoloji ve Metabolizma Bilim Dalı,

Konya, Türkiye.

${ }^{2}$ Selçuk Üniversitesi, Tıp Fakültesi, Nükleer

Tıp Anabilim Dalı, Konya, Türkiye.

Geliş Tarihi/Received: 16 Ağustos 2018

Kabul Tarihi/Accepted: 6 Ocak 2019

Yazışma Adresi: Cem Onur Kıraç, Selçuk Üniversitesi, Tıp Fakültesi, Endokrinoloji ve Metabolizma Bilim Dalı, Konya, Türkiye

e-posta: cokirac@gmail.com

ORCID

Cem Onur Kıraç

https://orcid.org/0000-0002-0249-9867

\begin{abstract}
Öz
Sessiz tiroidit ve Graves hastalığı otoimmün kökenli, tirotoksikoz tablosuyla karşımıza çıkabilecek, farkl tedaviler verilmesi gereken iki farkı hastalıktır. Bu iki hastalığın ayırıcı tanısında hikaye ve fizik muayene yeterli olmamakta, tiroid sintigrafisi, iyot re-uptake çalışması ve tiroid stimülan reseptör antikoru gibi ileri tetkiklere intiyaç duyulmaktadır. Bu vakada remisyonda Graves hastalığı nedeniyle takip edilen bir hastada gelişen tirotoksikoz tablosu sonucunda tetkik edilen ve sessiz tiroidit tanısı koyulan bir olgu sunulmuş ve bu iki hastalığın ayırıcı tanısının önemi vurgulanmıştır.
\end{abstract}

Anahtar Kelimeler: Graves hastalığı, sessiz tiroidit, tirotoksikoz.

\section{Abstract}

Silent thyroiditis and Graves' disease are autoimmune disorders which are common cause of thyrotoxicosis and should be given different treatments. Anamnesis and physical examination are not sufficient in the differential diagnosis of these two diseases, and advanced examinations such as thyroid scintigraphy, iodine reuptake study and thyroid stimulating receptor antibody could be needed. In this case, we present a patient diagnosed with a silent thyroiditis as a result of a thyrotoxicosis of a patient who was following up due to Graves' disease in remission and we aimed to emphasize the importance of differential diagnosis of these two diseases.

Keywords: Graves' disease, silent thyroiditis, thyrotoxicosis.

\section{GíRiş}

Sessiz tiroidit, destrüktif tiroid hasarı sonucu ortaya çıkan, henüz etiyolojisi tam olarak açıklanmasa da kronik otoimmün tiroid hastalıkları arasında sayılan bir tiroid hastalığıdır (1). Hastalığın patogenezinde supresör $T$ lenfositlerdeki defektin rol oynadığı düşünülmektedir (2). Graves hastalığı da aynı şekilde otoimmün tiroid hastalıkları spektrumunda yer almaktadır ve persistan tirotoksikozun en sık sebebidir (3). Tirotropin reseptör antikorları, özellikle tiroid stimulan antikor (TSAb), sıklıkla Graves hastalığında pozitif bulunurken bazı sessiz tiroidit vakalarında da saptanmıştır ancak hastalığın patogenezindeki önemi hala anlaşılamamıştır (4). Graves hastalığı öyküsü olan özellikle postpartum dönemdeki kadınlarda sessiz tiroiditin görülme sıklığı artmıştır ancak gebelikle bağlantıı olmadan da bu iki hastalığın ilişkisi bilinmektedir $(5,6)$. Bu olgu sunumunda nadir görülen bir vaka olarak Graves hastalığı ve sessiz tiroidit birlikteliğini literatür eşliğinde sunmayı amaçladık.

\section{OLGU}

Üç yıl önce çarpıntı, terleme, kilo kaybı şikayetleri ile başvuran 40 yaşındaki kadın hastanın o dönemdeki tetkiklerinde TSH: $0.005 \mu \mathrm{lU} / \mathrm{mL}$ (normal: 0.56-5.57), sT3: $8.5 \mathrm{pg} / \mathrm{mL}$ (normal: 2.3-4.2), sT4: $4.05 \mathrm{ng} /$ $\mathrm{dL}$ (normal: 0.93-1.7) olarak saptandı. Etiyolojiye yönelik tetkik edilen hastanın anti-tiroid peroksidaz antikoru $153 \mathrm{IU} / \mathrm{mL}$ (normal: 0-34) ve anti-tiroglobulin antikoru $546 \mathrm{IU} / \mathrm{mL}$ (normal: 0-115) olarak bulundu. Sonrasında istenen tiroid sintigrafisinde tiroid bezinde radyoaktif madde tutulumunun homojen olarak arttığı gözlendi ve hastaya Graves hastalığı tanısı koyuldu (Şekil 1). Sonrasında propiltiourasil tedavisi

Atıf yapmak için: Kıraç CO, İpekçi SH, Gedik GK, Kebapcılar L. Graves Hastalığının Remisyon Döneminde Sessiz Tiroidit. Selcuk Med J 2019;35(3): 207-209 


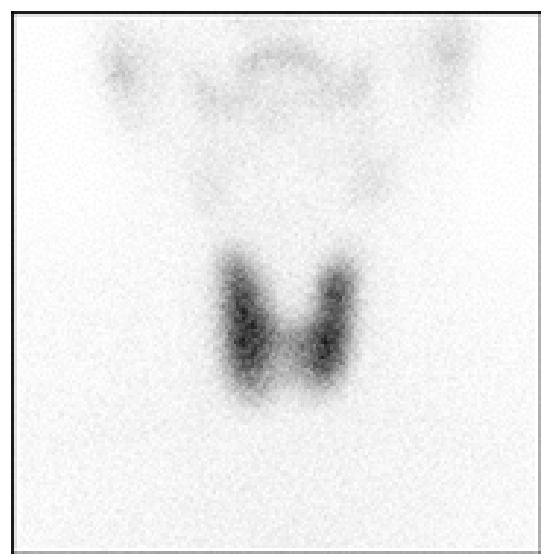

Şekil 1. Diffüz hiperaktif tiroid bezi

başlanan hasta düzenli olarak görüldü ve ilaç dozu ayarlandı. Tedavinin 18. ayına kadar ötiroid halde takip edilen hastanın tedavisi kesildi ve takiplere çağırıldı. Tedavisiz izlemin 18. ayında hasta çarpıntı, terleme şikayetleri ile tekrar polikliniğimize başvurdu. Hastanın fizik muayenesinde tiroid bezi palpable idi. Tiroid lojunda ağrı, hassasiyet saptanmadı. Ellerde tremor tespit edildi. Hastanın önerilen iyotsuz diyete tam olarak uymadığı öğrenildi. Yapılan tetkiklerinde TSH: $0.006 \mathrm{mU} / \mathrm{L}$, sT3: $3.54 \mathrm{ng} / \mathrm{L}$, sT4: $1.6 \mathrm{ng} / \mathrm{dL}$ olarak tespit edildi. Tiroid sintigrafisinde tiroid bezinin bariz süprese olduğu görüldü (Şekil 2). Hastaya sessiz tiroidit tanısı koyularak semptomlarına yönelik propranolol tedavisi başlandı. Bir ay sonra kontrolde şikayetlerinin gerilediği öğrenilen hastanın tetkiklerinde TSH: $10.08 \mathrm{mU} / \mathrm{L}$, sT4: $0.894 \mathrm{ng} / \mathrm{dL}$, sT3: $2.59 \mathrm{ng} / \mathrm{L}$ olarak görülmesi üzerine hastanın

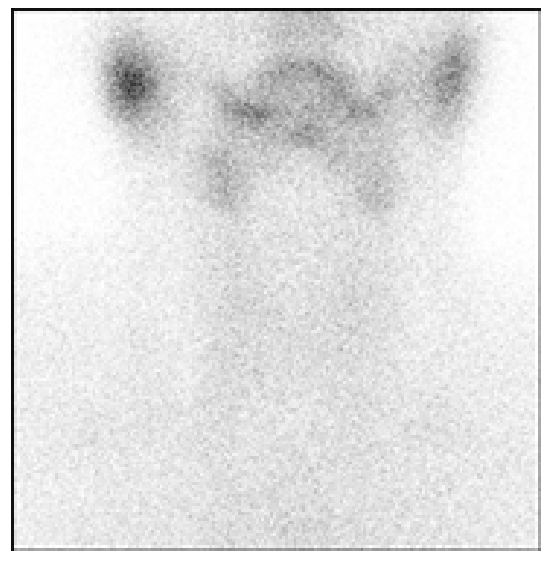

Şekil 2. Bariz suprese tiroid bezi propranolol tedavisi kesilerek levotiroksin tedavisi başlandı.

\section{TARTIŞMA}

Sessiz tiroidit tablosu sıklıkla postpartum dönemde bazen de sporadik olarak ortaya çıkan otoimmün orijinli bir hastalıktır (7). Tirotoksikoz fazıyla başlar ve bu dönemi hipotiroid ve ötiroid fazlar takip eder. En sık 30-50 yaş arası kadınlarda görülür (8). Antikor pozitifiliği, tirotoksikoz semptomlarının aynı olması, hastalıkların sıklıkla görülen yaş aralığı benzer olmasından dolayı sessiz tiroidit ve Graves hastalığının ayırıcı tanısı oldukça önemlidir. Çünkü bu iki hastalığın tedavisi birbirinden tamamen farklıdır. Sessiz tiroiditlerde radyoaktif iyot uptake'i düşük ve hemen daima \%3'ün altında bulunurken Graves hastalığında artmış tutulum görülür (9). Antitiroid tedavi sonrası remisyona giren Graves hastalığının nüksü ile sessiz tiroiditin ayırıcı tanısında kullanılabilecek bir başka tetkik ise TSAb'tır (10). Yine de Graves hastalarının \%5-10'unda TSAb negatifliği olabilecekken, bazı sessiz tiroiditlerde TSAb pozitifliği görüldüğü unutulmamalıdır $(4,11)$. Aynı zamanda maalesef ülkemizde birçok merkezde TSAb tetkiki çalışılamamaktadır. Ayırıcı tanıda kullanılabileceği düşünülen oftalmopati, Graves hastalığında \%40 oranında görülürken sessiz tiroiditte de nadiren de olsa görülebileceği akılda tutulmalıdır (12).

Sonuç olarak remisyonda Graves hastalığı nedeniyle takip edilen hastalarda gelişen tirotoksikoz tablosu sonrası hastayı nüks Graves olarak kabul etmeden önce diğer tirotoksikoz nedenleri dışlanmalı, yanlış veya gereksiz tedavi verilmemelidir. Ayırıcı tanıda özellikle tiroid sintigrafisi, iyot re-uptake çalışması ve TSAb kullanılabilir.

Çıkar Çatışması: Çalışmada herhangi bir çıkar çatışması yoktur.

Finansal Çıkar Çatışması: Çalışmada herhangi bir finansal çıkar çatışması yoktur.

Yazışma Adresi: Cem Onur Kıraç, Selçuk Üniversitesi, Tıp Fakültesi, Endokrinoloji ve Metabolizma Bilim Dalı, Akademi Mahallesi, Celal Bayar Cd. No:313, 42130 Selçuklu/Konya Telefon: +90553 3281158

Email:cokirac@gmail.com

\section{KAYNAKLAR}

1. Pearce EN, Farwell AP, Braverman LE. Thyroiditis. N Engl J Med 2003;348(26):2646-55.

2. Strakosch CR. Thyroiditis. Aust N Z J Med 1986;16(1):91100.

3. Leo SD, Lee SY, Braverman LE. Hyperthyroidism. Lancet 2016;388:906-18. 
4. Morita T, Tamai H, Oshima A, et al. The occurrence of thyrotropin binding-inhibiting immunoglobulins and thyroidstimulating antibodies in patients with silent thyroiditis. J Clin Endocrinol Metab 1990;71(4):1051-5.

5. Check JH, Avellino J. Painless thyroiditis and transient thyrotoxicosis after Graves' disease. JAMA 1980;244:1361.

6. Nakamura S, Saio Y, Shimada T, et al. Transient hypothyroidism in a case of untreated Graves' disease. Endocrine J 1995;42:77-81.

7. Dayan CM, Daniels $\mathrm{GH}$. Chronic autoimmune thyroiditis. N Engl J Med 1996;335:99-107.

8. Singer PA. Thyroiditis: Acute, subacute, and chronic. Med Clin North Am 1991;75:61-77.

9. Farwell AP, Braverman LE. Inflammatory thyroid disorders. Otolaryngol Clin North Am 1996;29:541-56.
10. Izumi Y, Takeoka K, Amino N. Usefulness of the 2 nd generation assay for anti-TSH receptor antibodies to differentiate relapse of Graves 'thyrotoxicosis from development of painless thyroiditis after antithyroid drug treatment for Graves' disease. Endocr J 2005;52:493-7.

11. Ilicki A, Gamstedt A, Karlsson FA. Hyperthyroid Graves' disease without detectable thyrotropin receptor antibodies. J Clin Endocrinol Metab 1992;74:1090-4.

12. Gopinath B, Ma G, Wall JR. Eye signs and serum eye muscle and collagen XIII antibodies in patients with transient and progressive thyroiditis. Thyroid 2007;17:1123-9. 